\title{
Professional Commitment of Government and Private School Teachers with Special Reference to their Rural Urban Dichotomy
}

\author{
Dr. Aashiq Ahmad Thoker
}

Lecturer Department of Education J \& K

\begin{abstract}
The present study was conducted to find and compare the professional commitment of Government and private School teachers on sex and rural and urban dichotomy. 800 Government and private School teachers were selected by using random cum stratified sampling technique. Professional Commitment Scale developed by Ravinder Kaur Ranu and Sarvjeet Kaur Brar was uses for data collection. The data was subjected to statistical treatment by using percentage, Mean, Standard Deviation, and ' $t$ ' test. Results revealed that Government and private School teachers differ significantly on various levels of professional commitment. Private School teachers were found high committed towards their profession as compared to Government School teachers. Further, it was found that locality has significant impact on professional commitment of School teachers, urban School teachers were found more committed as compared to rural school teachers
\end{abstract}

Keywords: Professional Commitment, Government, and Private School Teachers, Rural urban Dichotomy.

\section{INTRODUCTION}

Professional commitment of teachers is reported to have a pre-established significance in which employees establish the effective bond of agreement related to professional behaviour. It ensures that a teacher should be out rightly committed to his work to acquire necessary knowledge and skills without any effective background. Professional commitment of teaching personnel means a feeling of dedication towards their profession. Committed teachers not only seek all round development of children but work for their own professional growth. Commitment of teachers has been identified as one of the most critical factor for the future success of education and schools. Professional commitment is the willingness to engage with the school community. It is a belief that reaches out beyond the four walls of the classroom and perhaps even extends beyond the boundary of the school. It is typically conceived as individualse psychological bond to the organization including a sense of job involvement, loyalty and belief. Vandenberg, R.J. \& Scarpello, V. (1994) advocates, "professional commitment as a person's belief and acceptance of the values of his or her chosen occupation or line of work, and a willingness to maintain membership in that occupation". Professional Commitment acts as a bridge between the acceptance of the goals and values of profession and a willingness to exert considerable effort on behalf of the profession. According to Lodahl, T.M. and Kejner, M. (1965), "professional commitment is the degree to which a person" s work performance affects his self-esteem". Salancik, G.R. (1977) pointed out, "the concept of commitment is attitudinal in nature. It reflects the close proximity of an individual with his organization or relationship. According to Morrow and Madhu and Indu (2015) revealed a significant difference in professional commitment among teacher educators working in government aided and self-financing B.Ed. colleges. Teachers belonging to self-financing institutions were found more committed towards their job as compared to government teachers. Mary and Annaraja (2015) found no significant difference between arts and science stream male and female teachers in professional commitment. Khan (2015) revealed significant mean difference between organizational commitment of public and private school teachers. Private school teachers were observed to experience more commitment as compared to the public school teachers. Shukla (2014) observed no significant difference between teaching competency of teachers on high and low levels of job satisfaction. Arjunan, M. \& Balamurugan, M. (2013) found no any variation between male and female teachers on professional commitment. Professional commitment of school teachers was found positively inclined towards the welfare of students, society, human values and academic excellence. Sharma (2013) revealed no influence of locality on teaching effectiveness of secondary school teachers. Significant relationship between teaching effectiveness 
and professional commitment of secondary school teachers has also been confirmed. Guven, $O$. (2012) reported significant difference between private school teachers and government school teachers on level of organizational commitment.

Therefore, keeping this thing into consideration efforts have been made by the present researcher to study the research problem as:

\section{Statement of The Problem}

Professional Commitment of Government and Private School Teachers with special reference to their rural urban dichotomy.

\section{OBJECTIVES OF THE STUDY}

The following objectives have been formulated for the present investigation:

To study and compare professional commitment of Government and private school teachers.

To study and compare professional commitment of rural and urban school teachers.

\section{HYPOTHESIS}

Based upon the above mentioned objectives, the following hypotheses were formulated:

There is significant difference between professional commitment of Government and private school teachers.

$>$ There is significant difference between professional commitment of rural and urban school teachers.

\section{OPERATIONAL DEFINITIONS OF THE TERMS AND VARIABLE:}

\subsection{Professional Commitment}

Professional commitment in the present study refers the dominant set of scores obtained by the respondents on professional commitment scale developed by the Ravinder Kaur Ranu and Sarvjeet Kaur Brar (2011).

\subsection{School Teachers}

Secondary school teachers in the present investigation refer to those teachers who are working at +2 level in higher secondary schools either run by the Government or private trusts/ organizations.

\section{Delimitations OF THE StUdy}

Keeping in view the availability of time, budget schedule and limited resources, the present study has been delimited to:

The teachers working in Government and private higher secondary schools,

The two demographic variables of the respondents i.e. rural and urban dichotomy and

Five districts of the valley viz. Srinagar, Anantnag, Shopian, Pulwama and Kulgam.

\subsection{Methodology}

Keeping in view the research evidences, objectives and hypotheses, the researcher found it suitable to go through descriptive survey method, through which data was collected.

\section{SAMPLE}

The present investigation was carried out on a sample of 800 teachers working in Government and private Secondary Schools of Kashmir Valley. These teachers were drawn from five districts: Srinagar, Anantnag, Shopian, Pulwama and Kulgam. A random sampling technique was adopted to carry out the investigation. The age of the subjects was between 30 to 50 years.

\section{TOOLS USED}

The investigator, after screening a number of available tools, selected the following research tools to collect the required information. 
Professional Commitment of Government and Private School Teachers with Special Reference to their Rural Urban Dichotomy

\subsection{Professional Commitment}

Professional Commitment scale developed by Ravinder Kaur, Sarbjit Kaur, Ranu \& Sarvjeet KaurBrar (2011).

\subsection{Statistical Techniques Employed}

Information gathered was put to suitable statistical analysis by computing Percentage, Mean, S.D and test of significance (t-test).

\subsection{Analysis of Data}

Table1.1. Showing the Percent-wise Distribution of Government and Private School Teachers on Various Levels of Professional Commitment.

\begin{tabular}{|l|l|l|l|l|}
\hline \multirow{2}{*}{ Levels of Professional Commitment } & GST & PST & \%age \\
\cline { 2 - 5 } & $\mathrm{N}$ & \%age & $\mathrm{N}$ & 73.25 \\
\hline High Commitment & 1 & 0.25 & 73 & 42.25 \\
\hline Above Average Commitment & 52 & 13.00 & 169 & 26.50 \\
\hline Average Commitment & 116 & 29.00 & 106 & 8.00 \\
\hline Below Average Commitment & 30 & 7.50 & 32 & 5.00 \\
\hline Low Commitment & 201 & 50.25 & 20 & 100 \\
\hline Total & 400 & 100 & 400 & \\
\hline
\end{tabular}

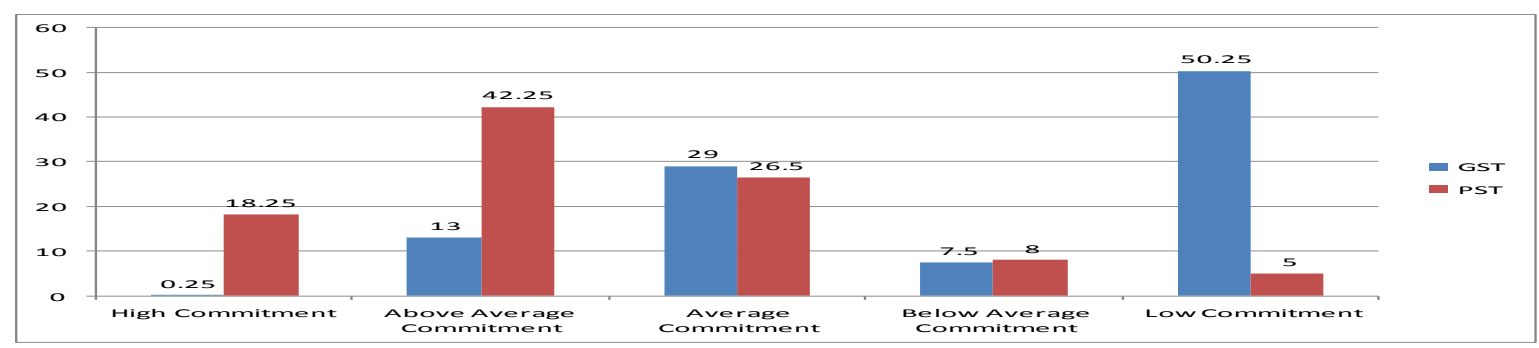

Fig.1.1. Comparison of Government and School Teachers on Various Levels of Professional Commitment.

Index: PST: Private School Teachers

GST: Government School Teachers

Table1.2. Showing the Percent-wise Comparison of Rural and Urban School Teachers on Various Levels of Professional Commitment.

\begin{tabular}{|l|l|l|l|l|}
\hline \multirow{2}{*}{ Levels of Professional Commitment } & RST & UST & \%age \\
\cline { 2 - 5 } & $\mathrm{N}$ & \%age & N & 18.25 \\
\hline High Commitment & 1 & 25 & 73 & 30.25 \\
\hline Above Average Commitment & 100 & 25 & 121 & 41.5 \\
\hline Average Commitment & 56 & 14 & 166 & 6 \\
\hline Below Average Commitment & 38 & 9.5 & 24 & 4 \\
\hline Low Commitment & 205 & 25.25 & 16 & 100 \\
\hline Total & 400 & 100 & 400 & \\
\hline
\end{tabular}

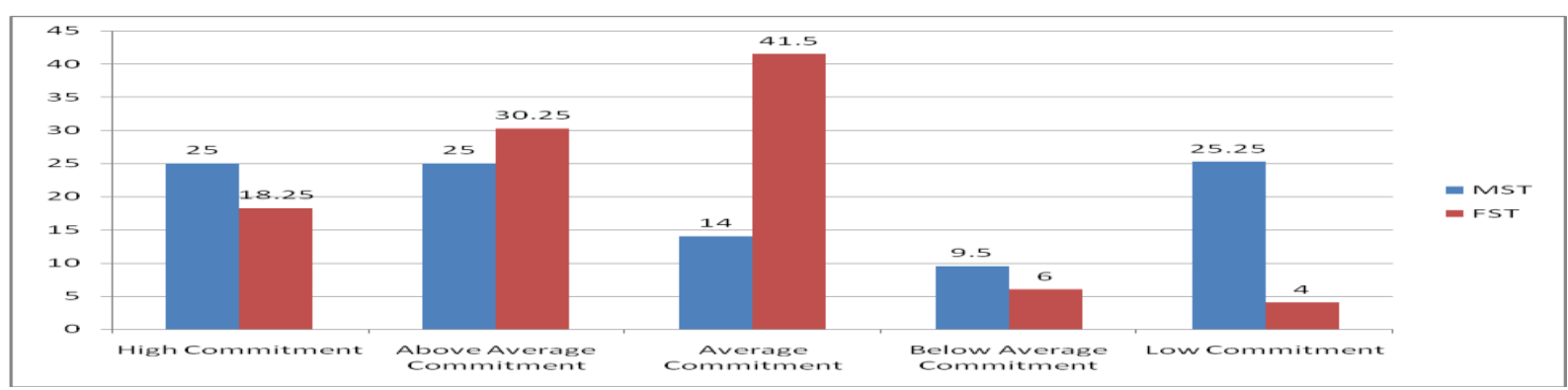

Fig1.2. Comparison of Rural and Urban School Teachers on Various Levels of

Professional Commitment.

Index: RST: Rural School Teachers

UST: Urban School Teachers 
Table1.3. Showing the Significance of Difference Between the Mean Scores of Government and Private School Teachers on Various Dimensions of Professional Commitment ( $N=400$ each).

\begin{tabular}{|l|l|l|l|l|l|l|}
\hline \multicolumn{2}{|l|}{ Dimensions of Professional Commitment } & PST & \multicolumn{2}{l|}{ GST-value } \\
\cline { 3 - 7 } & Mean & S.D & Mean & S.D & \\
\hline I & Commitment to Learner & 35.54 & 4.51 & 28.09 & 8.89 & $14.93^{* *}$ \\
\hline II & Commitment to the Society & 34.92 & 4.96 & 25.11 & 8.98 & $19.09^{* *}$ \\
\hline III & Commitment to the Profession & 35.00 & 6.15 & 24.80 & 9.75 & $17.61^{* *}$ \\
\hline IV & Commitment to Attain Excellence & 33.53 & 6.25 & 26.31 & 7.58 & $17.69^{* *}$ \\
\hline V & Commitment to Basic Human Values & 35.48 & 4.65 & 26.50 & 9.05 & $17.65^{* *}$ \\
\hline V & Composite Score & 163.23 & 29.16 & 142.07 & 40.00 & $8.54^{* *}$ \\
\hline
\end{tabular}

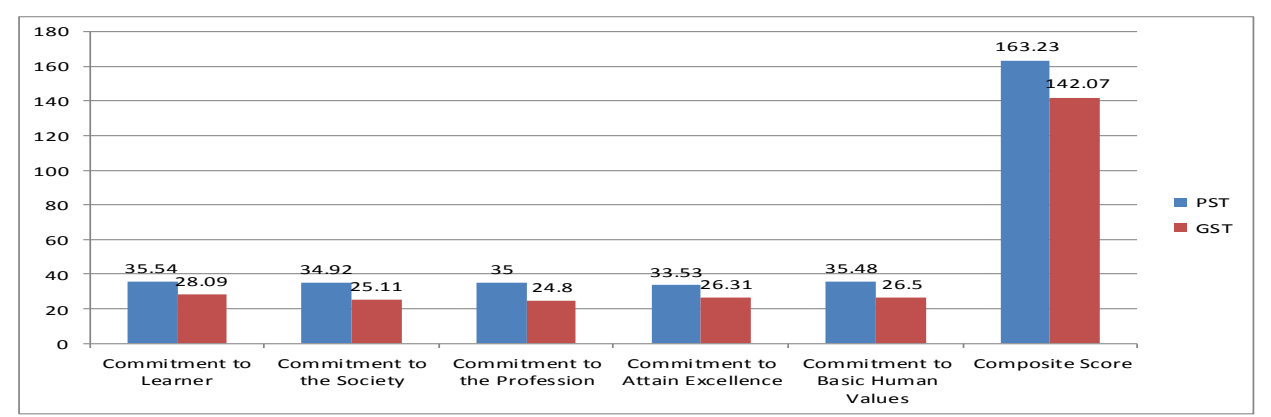

Fig1.3.Comparison of Government and Private School Teachers on Various Dimensions of Professional Commitment

Index: PST: Private School Teachers

GST: Government School Teachers

** Significant at 0.01 level of confidence

Table1.4. Showing the Significance of Difference between the Mean Scores of Rural and Urban School Teachers on Various Dimensions of Professional Commitment ( $N=400$ each).

\begin{tabular}{|l|l|l|l|l|l|l|}
\hline \multirow{2}{*}{ Dimensions of Professional Commitment } & RST & UST & t-value \\
\cline { 3 - 8 } & Mean & S.D & Mean & S.D & 12.30** \\
\hline I & Commitment to Learner & 28.63 & 9.43 & 34.99 & 4.24 & $12.47^{* *}$ \\
\hline II & Commitment to the Society & 26.02 & 10.34 & 34.01 & 3.81 & 14.4 \\
\hline III & Commitment to the Profession & 25.38 & 10.62 & 34.42 & 5.58 & $15.07^{* *}$ \\
\hline IV & Commitment to Attain Excellence & 25.40 & 7.95 & 34.43 & 4.31 & $19.95^{* *}$ \\
\hline V & Commitment to Basic Human Values & 26.85 & 9.26 & 35.13 & 4.89 & $15.79^{* *}$ \\
\hline V & Composite Score & $\mathbf{1 3 0 . 8 2}$ & $\mathbf{3 7 . 7 3}$ & $\mathbf{1 7 4 . 4 8}$ & $\mathbf{1 7 . 2 3}$ & $\mathbf{2 1 . 0 7 * *}$ \\
\hline
\end{tabular}

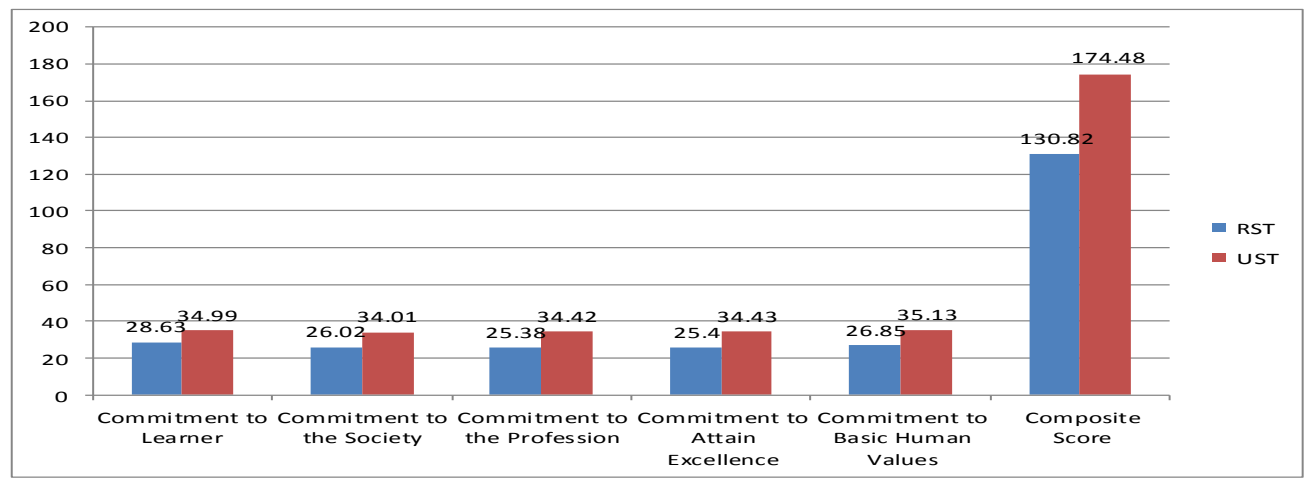

Fig1.4. Comparison of Rural and Urban School Teachers on Various Dimensions of Professional Commitment.

Index: RST: Rural School Teachers

UST: Urban Higher Secondary School Teachers

** Significant at 0.01 level of confidence

\subsection{Interpretation of Data}

The results presented in Table 1.1 (Fig. 1.1) reveals that in case of teachers belonging to private organizations, $18.25 \%$ were found highly committed, $42.25 \%$ private school teachers in above average level, $26.50 \%$ in the category of average, $8 \%$ in below average level of commitment and $5 \%$ 
in low level category on professional commitment. However, in case of Government school teachers, $0.25 \%$ are reported to be highly committed and $13 \%$ in the above average level of professional commitment. 29\% Government school teachers are observed in the level of average commitment, $7.50 \%$ in the level of below average commitment. In the same table, majority $(50.25 \%)$ of the teachers from the Government schools are seen in the low level category of commitment towards their profession.

Table 1.2 (Fig. 1.2) gives details about the percent-wise distribution of rural and urban teachers on different levels of professional commitment. It has been reported that $51.25 \%$ seems to have low professional commitment. 25\% above average commitment and 14\% in the level of average professional commitment. The table further reveals $9.5 \%$ subjects in the level of below average $0.025 \%$ high professional commitment. Whereas, in case of urban teachers, the percent-wise distribution on each level of professional commitment was noticed as: $41.5 \%$ above average, $30 \%$ as above average, $18.25 \%$ as highly committed. The results further revealed that $6 \%$ and $4 \%$ teachers from urban locale were observed in the category of below average and low level on professional commitment respectively.

The results presented in Table 1.3 (Fig. 1.3) gives information about the mean comparison of Government and private school teachers on various dimensions of professional commitment. While regard to first dimension of the professional commitment scale (Commitment to Learner), the mean score in case of private school teachers was found to be 35.54; which is higher than the mean score of Government teachers $(\mathrm{M}=28.09)$. The calculated ' $\mathrm{t}$ ' value has been observed to be 14.93 which is significant at 0.01 level of confidence. The results may be attributed to the fact that private teachers make their teaching as a joyful experience and remain duty bound for creating all round development of their learns. With regard to the comparison on second dimension (Commitment to Society) of the professional commitment scale, the mean score of teachers working in Government schools has been found to be 25.11, whereas the mean score of private school teachers has been found to be 34.92. The mean comparison led the investigator in the establishment of a significant difference between the mean score of teachers at 0.01 level $(\mathrm{t}=10.09)$. The results on third dimension of the professional commitment scale (Commitment towards Profession), revealed that private school teachers have higher mean $(\mathrm{M}=35.54)$ as compared to Government school teachers $(\mathrm{M}=28.09)$. The calculated ' $\mathrm{t}$ ' value came out to be 17.61 which is significant at 0.01 level of confidence. On the basis of these results, it can be said that private school teachers are more committed towards their profession as compared to Government school teachers. A quick glance towards the fourth dimension of professional commitment scale (Commitment to Attain Excellence) gives information about the mean comparison of private and Government teachers, the mean score in case of private school teachers has been found to be higher $(\mathrm{M}=33.53)$ as compared to the mean score of teachers belonging to Government schools $(M=26.31)$. The calculated ' $t$ ' value is reported to be 17.69 which is significant at 0.01 level of confidence. On the basis of the results it is revealed that private school teachers consider teaching a profession which requires continuous learning environment. While looking into the mean comparison of private and Government teachers on fourth dimension (Commitment to Basic Human Values) of professional commitment scale, the mean score in case of private school teachers was reported to be 35.48 which seems to be higher than the mean score of Government school teachers $(\mathrm{M}=26.50)$. The calculated ' $\mathrm{t}$ ' value was observed to be 17.65 , which is significant at 0.01 level of confidence. While comparing Government and private school teachers on composite score of profession commitment scale, private school teachers were seen to have a higher mean score $(M=163.23)$ in comparison to Government school teachers $(M=142.07)$. The calculated ' $t$ ' value came out to be 8.54 which is significant at 0.01 level of confidence. In the light of the results reported above the hypothesis, which reads as, "There is significant difference between professional commitment of Government and Private Higher Secondary School teachers.” stands retained. The results are supported by a host of researchers in this field (Nimisha, Anoop \& Beri, 2016; Khan, S. 2015; Madhu, 2015; Korso, 2013; Dhamane, 2013; Sushila and Ajay, 2012; Gupta and Gehlawat, 2012; Misra, and Khan 2009; Babu, Rama, \& Reddy. 2004; Amudha and Velayudhan 2003; Nair, 1997).

The results presented in the Table 1.4 (Fig. 1.4) give us the information about the mean comparison of rural and urban school teachers on various dimensions of professional commitment. With regard to the first dimension of professional commitment scale (Commitment to Learner), the mean score of 
urban teachers has been observed to be 34.99 , which seems to be higher than the mean score of rural teachers ( $M=26.63)$. The calculated ' $t$ ' value came out to be 12.30 which is significant at 0.01 level of confidence. Thus, on the basis of these results, it can be revealed that urban school teachers may be more committed towards the learners as compared to rural teachers. While analysing the results on the second dimension (Commitment to Society) of the professional commitment scale, the mean score in case of urban teachers has been reported to be higher (34.01) as compared to female teachers (26.02). The mean difference between was observed to be significant at 0.01 level of confidence (' $t$ ' $=5.90 ; \mathrm{p}$. $>0.01$ ). With regard to third dimension of the professional commitment scale (Commitment towards Profession), the results revealed that urban school teachers are reported to be higher mean $(\mathrm{M}=31.87)$ as compared to rural school teachers $(\mathrm{M}=27.93)$. The calculated ' $\mathrm{t}$ ' value came out to be 5.92 , which is significant at 0.01 level of confidence. On the basis of these results it can be said that urban school teachers are more committed towards their profession as compared to rural school teachers. In order to find the gender variation of teachers on the fourth dimension (Commitment to Attain Excellence) of professional commitment scale, urban group of teachers $(M=34.43)$ was found to have a positive inclination towards achieving excellence in their profession as compared to their counter parts $(M=25.40)$. The calculated ' $t$ ' value came out to be 5.77 which reveals the significant mean difference between the two groups under discussion. The results reported on fourth dimension of professional commitment scale (Commitment to Basic Human Values) revealed higher mean value ( $M=35.13)$ in case of urban teachers as compared to rural teachers $(\mathrm{M}=26.85)$. The obtained ' $\mathrm{t}$ ' value has been observed to be 15.79 which is statistically significant at 0.01 level of confidence. The mean difference favours urban group of teachers as compared to their counter parts. A perusal of the above table gives information about the composite score between rural and urban school teachers on professional commitment scale. The results revealed that the mean score in case of urban school teachers is 174.48 which is reported to be higher than the mean value of rural school teachers $(M=130.82)$. The operational ' $t$ ' value came out to be 15.79 which is significant at 0.01 level of confidence. It can be inferred that urban school teachers have an optimistic attitude among their students. In the light of the results reported above the hypothesis, which reads as, "There is significant difference between professional commitment of Rural and Urban Higher Secondary School teachers" stands retained. These results has been found in agreement with some of the studies carried out by other researcher. (Muhammad, et al., 2016; Shoib, Khalid \& Mahmood, 2015; Umender \& Dinesh 2013; Oziambo 2013; Bloom, 1988).

\section{Conclusions of THE Study}

$>$ The study revealed majority of the private school teachers on above average level of professional commitment. Whereas, majority of the Government teachers were observed in the category of low average on commitment towards their profession.

$>$ The study revealed majority of urban school teachers as above average on professional commitment as compared to school teachers belonging to rural background.

$>$ The investigator observed majority of the respondents from rural and urban background had positive attitude towards professional commitment.

> Private school teachers were seen to have high professional commitment as compared to Government school teachers. High level of commitment to learner, commitment to society, commitment to profession, commitment to attain excellence and commitment to basic human values was associated with teachers belonging private organisations.

- Urban school teachers were observed to possess a high level of professional commitment on all the dimensions viz. Commitment to learner, Commitment to Society, Commitment to Profession, Commitment to attain Excellence and Commitment to basic human values as compared to rural school teachers.

\subsection{Educational Implications}

The study stimulates towards the below mentioned implications:

Workshops and orientation programmes on the importance and inculcation of work ethics like commitment, self-discipline, loyalty, and work value should be organised for teachers in different training programmes. 
Every educational institution requires a supportive environment for their teachers. The teachers need to be familiarised to their personal skills, which will culminate in enhancing their commitment, competence and ethics.

D Every management must provide - security of service, adequate salary, appreciation of service, opportunities for professional advancement, status in the community or in social service organization - to their teaching personnel. This will in return build up confidence, commitment and efficacy among teachers towards their profession.

Regarding the execution of professional ethics and professional commitment, the school authorities are required to frame norms and statutes so that ethical standard among educational stakeholders is protected.

\section{SUGGESTIONS FOR FURTHER RESEARCH}

$>$ The present endeavour is not an exception rather it opens certain avenues for further research in the field of present investigation. However, following few suggestions are recommended in this behalf:

Work culture was observed important factor for determining professional commitment, so a study should be conducted on professional ethics in relation to work culture and work ethics.

$>$ A comparative study on professional ethics, professional commitment and occupational selfefficacy is recommended to be conducted on teachers at various levels like: primary, secondary, college and university.

$>$ The present piece of research was confined on variables- professional ethics, professional commitment and occupational self-efficacy, in relation to type of school and rural urban dichotomy. Therefore, similar investigations are recommended to be carried out on the variable of demographic profiles, socio-economic status, length of service and marital status.

It is recommended to undertake co-relational studies on the variables of professional ethics, professional commitment and occupational self-efficacy by involving teachers regulated by different autonomous organizations.

\section{REFERENCES}

[1] Agarwal,\&Agarwal, S. K(2012). A Study of Role Conflict in Relation to Professional Commitment, Frustration Tolerance and Teaching Attitude of Secondary School Teachers. Apex Institute of Management Studies and Research, Partapur Bypass, Meerut U.P.

[2] Amudha, Devi, N.V. \& Velayudhan, A. (2003). Job Satisfaction of Women Lecturers Working in Private and Government Colleges. Indian Journal of Applied Psychology, Vol.40. Pp.25-28.

[3] Arjunan, M., \& Balamurugan, M. (2013). Professional Commitment of Teachers Working in Tribal Area Schools. International Journal of Current Research and Development. Vol.2 No.1, Pp.65-74.

[4] Babu, V. Rama Mohan and Reddy, A. V. R. (2004) Organizational Climate of Schools in relation to Type of School and Sex of Teacher. Perspectives in Education. Vol. 12 No.3.

[5] Bloom, P. J. (1988). Factors Influencing Overall Job Satisfaction and Organizational Commitment in Early Childhood Work Environments. Journal of Research in Childhood Education. Vol. 3. No.2. Pp.107-122.

[6] Dhamane (2013) Bureau of International Narcotics and Law Enforcement Affair. Report International Narcotics Control Strategy Report (INCSR)

[7] Dov, Elizur Meni Koslowsky. (2001). Values and Organizational Commitment. International Journal of Manpower, Vol. 22 No.7. Pp.593 - 599.

[8] Gupta \& Gehlawat (2013). A Study of the Correlates of Organizational Commitment Among Secondary School Teachers. Journal of Issues and Ideas in Education (IIE), Vol. 1. Pp. 12-15.

[9] Güven Ozdem (2012). The Relationship between The Organizational Citizenship Behaviors And The Organizational And Professional Commitments Of Secondary School Teachers. Journal of Global Strategic Management. 
[10] Güven, O. (2012). The Relationship between the Organizational Citizenship Behaviours and the Organizational and Professional Commitments of Secondary School Teachers. Journal of Global Strategic Management. Vol. 1. No. 1. Pp. 17-21.

a. Involvement. Journal of Applied Psychology. Vol. 33. Pp.24-33.

[11] Irudhay \& Annaraja (2015). A Comparative Study of Job Satisfaction and Attitude Towards Education Among Male and Female Teachers of higher secondary schools. Vol. 1 No. 1. Pp. 6-7.

[12] Khan, S. (2015). Organizational Commitment among Public and Private School Teachers. The International Journal of Indian Psychology. Vol. 2. No. 3. Pp.17-19.

[13] Korso, G. B. (2013). Teachers' Perceived Commitment as Measured by Age, Gender and School Type. University of Eastern Africa, Baraton, Kenya. Greener Journal of Educational Research. Vol. 3. 8. Pp. 363-372

[14] Lodahl, T. M. and Kejner, M. (1965) The Definition and Measurement of Job

[15] Madhu, G. \& Indu, N. (2015). An Exploratory Study of Professional Commitment among Teacher Educators Working in B.Ed. Colleges. Bhartiyam International Journal of Education \& Research. Vol. 5. No.1.

[16] Madhu, G. \& Indu, N. (2016). Professional Commitment, Role Conflict and Life Satisfaction. A Gender Based Study of Teacher Educators. Galaxy International Interdisciplinary Research Journal. Vol.4. No.3. Pp. 25-34

[17] Mary \& Annaraja (2015). Professional Ethics in Nursing an Integrative Review. Journal of Advanced Nursing. Vol. 7. No. 8. Pp. 17-19.

[18] Mary M., I. \& Annaraja P. (2015) Professional Commitment of Arts and Science College. Conflux Journal of Education. Vol. 2. No. 11.

[19] Mary, H. S. (1998). Professional Commitment and Satisfaction Among Teachers in Urban Middle Schools. The Journal of Educational Research Volume. Vol. 92, No. 2.

[20] Mattoo, M. I. \& Thoker, A. A. (2015). Professional Ethics Scale. Insight Journal of Education. School of Education and Behavioural Science. University of Kashmir.

[21] Misra, S., Ansari, N. \& Khan, S., A. (2009). A Comparative Study of Organizational Commitment and Organizational Health among Public and Private School Teachers. Indian Journal of Psychology and Mental Health. Vol. 3. No. 5. Pp. 42-48.

[22] Muhammad \& Aruna (2014). A Comparative Study of Public and Private Primary Schools, with Perspective of Practice of Effective Teaching Activities and Outcomes. International Journal of Advanced Research.Vol. 2, No6, 501-509. Vol. 3, No. 8. Pp.7-15.

[23] Muhammad, et al. (2016). Relationship of Conflict Management Styles with Teacher's Professional Commitment. Science International, Vol. 28. No. 2.

[24] Nair, S. R. (1974). Impact of Certain Sociological Factors on Teaching Ability in the Classroom. Govt. Training College, Trichur (NCERT, Financial), India.

[25] Nimisha, B. \& Anoop, B. (2016). Professional Commitment of Teacher Educators in Relation To Work Motivation. International Journal of Research in Humanities, Arts and Literature. Vol. 4. No. 1.

[26] Ravinder, K., Sarbjit K., R. \& Sarvjeet, K. B. (2011). Professional Commitment Scale. National Psychological Corporation. UG-1 Nirmal Heights, Agra Mathura Road, Agra 282007-India.

[27] Richa, C., Santosh, R. \& Mukesh, K. B., (2012). "Relationships between Occupational SelfEfficacy, Human Resource Development Climate, and Work Engagement", Team Performance Management: An International Journal. Vol. 18. No. 14. Pp.370 - 383.

[28] Richa, C., Santosh, R. \& Mukesh, K., B. (2013). Engaged Versus Disengaged: The Role of Occupational Self-Efficacy. Asian Academy of Management Journal, Vol. 18. No. 1. Pp.91-108.

[29] Salancik, G. R. (1977).Commitment and the Control of Organizational Behaviour and Belief. B.M.Staw, G.R. Salancik (Eds.) New Directions in Organizational Behaviour.St.Clair Press, Chicago; 1977.

[30] Sharma (2008), The Commitment Among Teachers with Regard to Some of Their Personal and Academic Variables. Conflux Journal of Research. Vol. 15 Pp. 12-13. 
[31] Sharma, U., Loreman, T. \& Forlin, C. (2011). Measuring Teacher Efficacy to Implement Inclusive Practices. Journal of Research in Special Education Needs. Vol. 5. No. 9.

[32] Shiv, P., Astha, S. \& Santosh K. Y. (2016). Personality (Introvert, And Extrovert) and Professional Commitment Effect among B.Ed. Teacher Educator Students. The International Journal of Indian Psychology. Vol. 3. No. 2.

[33] Shoiab, H., Khalid, I. \& Mahmood, T. (2015). Teachers Working Commitment Level and their Professional and academic competences: A Pakistani perspective. The AYER, 2. Pp. 290-297.

[34] Shukla, S. (2014). Teaching Competency, Professional Commitment and Job Satisfaction of Primary School Teachers. Journal of Research \& Method in Education. Vol. 4, No. 3. Pp. 44-64.

[35] Sushila, S. \& Ajay, K. (2012). A Study of Professional Commitment in Relation to Thinking Style, Job Values and Teachers Effectiveness of Teachers Working in Teacher Training Institutions of Haryana. (Unpublished Ph. D. Thesis) Department of Education, University Rohtak C.R. College of Education Rohtak (Haryana).

[36] Umender, M. \& Manju, R. (2013). Relationship between Professional Commitment and Attitude towards Teaching among Secondary School Teachers. Indian Journal of Applied Research Vol. 3. No.10.

[37] Vandenberg, R. J. \& Scarpello, V. (1994). A Longitudinal Assessment of the Determinant Relationship Between Employee Commitment to the Occupation and The Organization. Journal of Organizational Behaviour. Vol. 15. No. 10. Pp. 535-547. 